\title{
Two Sources for Abu Dhu’ayb al-Hudhali's Famous Elegy
}

\author{
Ali Ahmad Hussein (D) \\ Department of Arabic Language and Literature, University of Haifa, Haifa, Israel \\ Corresponding author. ahussein@univ.haifa.ac.il
}

\begin{abstract}
This article considers the celebrated elegy by the classical 7th-century Arabic poet, Abu Dhu'ayb al-Hudhali his 'ayniyya, which ends with 'ayn as a rhyming letter. Analyzing the poem's structure and comparing it with that of two poems composed by Abu Dhu'ayb's teacher, Sa 'ida b. Ju'ayya al-Hudhali, leads to the conclusion that Sa'ida's two poems were the main sources on which the pupil drew to create his poem. The sophisticated changes that Abu Dhu'ayb introduced in structure and content, however, made his poem more memorable than those of his teacher. The article raises another question, to which there is, as yet, no definitive answer: what was the true inspiration for Abu Dhu'ayb's poem? Was it the death of his sons, as is traditionally believed, or was it literary: to surpass his teacher in composing a more skillful poem?
\end{abstract}

Keywords: Abu Dhu’ayb al-Hudhali; 'ayniyya; classical Arabic poetry; elegy; plague; Sa'ida b. Ju’ayya al-Hudhali

This article is written during a time when a deadly virus-COVID-19-is attacking the world, from west to east and north to south. About a millennium and half ago, a similarly aggressive plague attacked Egypt. According to historical records, among those killed by this ancient plague were the sons of Abu Dhu'ayb al-Hudhali, a Muslim poet (d. ca. 649 A.D.). Originally from the Hejaz region, in the west of the Arabian Peninsula, he, with other Muslims, migrated to Egypt after the country's conquest in 641 A.D. His response to the catastrophic loss of all five of his sons in the same year, the story relates, was the composition of his famous elegy, a sixty-three-line poem said to be a requiem for them. ${ }^{1}$

Because the poem ends with the 'ayn as a rhyming letter, it is called the 'ayniyya of Abu Dhu'ayb. It opens with the celebrated verse (in kämil meter):

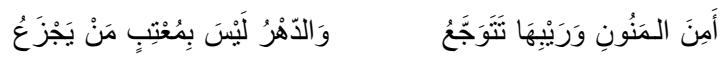

Why do you grieve at Fate and its mischief, for Fate never shows good will to those who sorrow. ${ }^{2}$

Elegies (in Arabic, marāthī, sing. marthiyya) originated as a female rather than a male composition. In the elegy's earliest form, it was women who composed verses to eulogize the deceased, usually a relative, aiming to appease the soul of the dead, and, if the deceased was male, to commemorate his noble qualities and give expression to the grief of his family. Women gave passion and intensity to their elegies. Later, men began composing them too, with some of them owing their reputation almost entirely to the genre. ${ }^{3}$ One of the most famous elegies written by a male poet was Abu Dhu'ayb's 'ayniyya. It has since been translated into several European languages and studied by modern scholars. Despite its fame, however, its authenticity has been called into doubt by Charles Pellat, a brilliant French Arabic literature scholar

\footnotetext{
${ }^{1}$ This is according to Abu Said al-Hasan b. al-Husayn al-Sukkari, Kitab Sharh Ashiar al-Hudhaliyyin, ed. 'Abd al-Sattar Ahmad Farraj (Cairo: Maktabat Dar al-'Uruba, 1965), 3-41.

${ }^{2}$ The English translation of the poem used in this article, sometimes slightly modified, is from Alan Jones, Early Arabic Poetry: Select Poems (Reading, UK: Ithaca Press, 2011), 493-524. Another translation, by al-Mufaddal al-Dabbi, is found in The Mufaddaliyat: An Anthology of Ancient Arabian Odes, ed. Charles James Lyall (Oxford, UK: Clarendon Press, 1918), 355-61. In Jones, the poem comprises sixty-two verses. In Lyall, it runs to sixty-four.

${ }^{3}$ Charles Pellat, "Marthiya," in The Encyclopaedia of Islam, 2nd ed. (Leiden: E. J. Brill, 1960-2004), 6:603.

(c) The Author(s), 2021. Published by Cambridge University Press. This is an Open Access article, distributed under the terms of the Creative Commons Attribution licence (http://creativecommons.org/licenses/by/4.0/), which permits unrestricted re-use, distribution, and reproduction in any medium, provided the original work is properly cited.
} 
(1914-92). ${ }^{4}$ He provides no evidence for his skepticism, but there is nonetheless good reason for itnamely, the very close similarity in structure and content between this elegy and two composed by another poet with the same tribal affinity, Sa'ida b. Ju'ayya al-Hudhali (see the Arabic text of Sa'ida's poems in addition to an English translation in the appendix to this paper). This article explores the commonality between these three poems for the first time.

Before considering the structural and content relationship between Abu Dhu'ayb's famous 'ayniyya and the two less- or non-famous poems, it is helpful to shed light on Abu Dhu'ayb himself. According to the renowned scholar Renate Jacobi, he was "the greatest poet of the Arabian tribe Hudhayl and one of the most original poets of his time." This opinion was shared by classical authorities. ${ }^{5}$ Native to the Hudhayl tribal lands in the southwestern Arabian Peninsula, Abu Dhu'ayb likely converted to Islam in 630 A.D. and moved to Medina shortly afterward in the summer of 632, following the death of Prophet Muhammad. ${ }^{6}$ After several years in Medina, he migrated to Egypt. Although we have no precise date, it is unlikely to have been earlier than 641, when Egypt fell to the Muslims. The year 648 saw him march on North Africa with the Egyptian army under the command of its governor, 'Abd Allah b. Abi Sarh. ${ }^{7}$ Along with 'Abd Allah b. al-Zubayr (a Muslim soldier, who decades later became an anticaliph and was killed in 692), Abu Dhu'ayb was dispatched to the Muslim caliph, 'Uthman b. 'Affan, in Medina with news of the fall of the city of Carthage. He never arrived, dying on the journey. ${ }^{8}$ This biography suggests that Abu Dhu'ayb composed his 'ayniyya sometime between 641 and 649, if the supposition that it is an elegy for his dead sons is correct. In classical Arabic poetry collections, poems are sometimes presented together with prose anecdotes that describe their occasions. With the poem by Abu Dhu'ayb, there is a prose narrative relating that

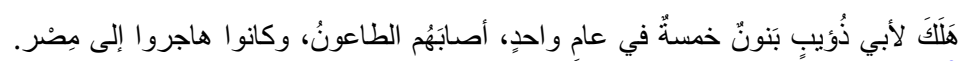

Five sons of Abu Dhu'ayb died in the same year of plague, after migrating to Egypt. ${ }^{9}$

The poem survives in slightly different versions. This article uses that which appears in Kitab Sharh Ashiar al-Hudhaliyyin (The Commentary on the Hudhalian Poems), which was collected and discussed by the Baghdadi scholar Abu Said al-Sukkari (d. 888). This collection is the sole surviving diwan (collections of poetry)of an Arab tribe (the Hudhayl) from the pre- and early Islamic period, and it is the only classical source that gathers the poetry of Abu Dhu'ayb and Sa'ida b. Ju'ayya, as well as of many other poets from the same tribe. It is, therefore, the sole source for the other two poems discussed in this article. This version of the 'ayniyya comprises sixty-three verses. Others have a slightly different number, but maintain the same structure as in al-Sukkari's anthology. ${ }^{10}$ The 'ayniyya has been translated into English and other languages and been competently analyzed by several scholars,

\footnotetext{
${ }^{4}$ Ibid.

${ }^{5}$ Muhammad Ibn Sallam al-Jumahi, Tabaqat Fuhul al-Shu'ara', ed. Mahmud Muhammad Shakir (Jidda: Dar al-Madani, 1974), 131; Renate Jacobi, “Abu Dhu'ayb," The Encyclopaedia of Islam, Three, Brill, accessed on 4 February 2021, https:// referenceworks.brillonline.com/browse/encyclopaedia-of-islam-3.

${ }^{6} \mathrm{He}$ visited the courtyard of the Banu Sa ida during the negotiations that preceded the nomination of Abu Bakr as successor to the Prophet Muhammad in the aforementioned year. See G. Lecomte, "al-Sakifa," in The Encyclopaedia of Islam, 8: 887.

${ }^{7}$ For the dates of 'Abd Allah b. Abi Sarh's conquest of North Africa, see Enayotallah Fatehi-Nezhad, "Abd Allah b. Sa'd," trans. Jawad Qasemi, in Encyclopaedia Islamica (Leiden: E. J. Brill, 2008), 1:181. According to the entry, 'Abd Allah b. Abi Sarh attacked North Africa in 648, 649, or 650 A.D. in an eighteen-month campaign, and in 649 helped Syrian governor Mu'awiya b. Abi Sufyan conquer Cyprus. As his role in subduing Cyprus would have been undertaken only after completion of his mission in North Africa, it is likely that the attack on North Africa began in 648.

${ }^{8 c}$ Ali Ahmad Husayn, al-Shakl wa-l-Madmun fi al-Shic $r$ al-'Arabi al-Qadim: Dirasat al-Ma'cani wa-l-Mabani fi Ashiar Sa'ida b. Juayya wa-Abi Dhu'ayb al-Hudhaliyyayn (PhD diss., University of Haifa, 2002), 13-14; n. 2-3.

${ }^{9}$ See al-Sukkari, Kitab, 3.

${ }^{10}$ In addition to the versions mentioned in footnote 2 , the Mufaddaliyyat anthology includes a version of the poem with sixtyfive verses; see al-Mufaddal al-Dabbi, Poem 26, in al-Mufaddaliyyat, 6th ed., ed. Ahmad Muhammad Shakir and 'Abd al-Salam Muhammad Harun (Cairo: Dar al-Ma'arif, n.d.), 421-29. The same poem has sixty-seven verses in Abu Zayd Muhammad b. al-Khattab al-Qurashi, Jamharat Ashiar al-'Arab fi al-Jahiliyya wa-l-Islam, ed. 'Ali Muhammad al-Bijadi (Egypt: Nahdat Misr li-1-Tibac a wa-1-Nashr wa-1-Tawzic, 1981[?]), 534-54.
} 
among them Albert Arazi and, both lexically and from the viewpoint of content, Alan Jones in his book on the Arabic elegies. ${ }^{11}$ Rather than repeat this earlier work and discuss the poem word by word, my aim here is to elucidate the poem's content through an analysis of its structure.

The poem can be broken into four discrete sections. It opens with a fourteen-verse prelude (assigned here the letter A), which first muses on death and the invincibility of fate and then portrays the extreme distress in body and soul of a father who buries his sons. This is followed by three episodes (B, C, and D), each of which underscores the relentless power of fate, as introduced in the prelude. All open with a similar phrase: و الدَّهرُ لا ييقى على حَدَثانِهِ (Nothing remains of the days, or Fate there survives not against its accidents; v. 15, 36, 49)-connecting each episode to the poem's theme of death. The first episode (B) tells the story of a small herd of onagers, comprising a male and four females. There is a description of the good life enjoyed by the herd in a lush meadow (v. 15-19), where the females frolic together, the male sometimes joining them, and sometimes taking sexual pleasure with them (طَوَتَنُُْ سَدْحَجُ , a slim-bodied mate complied with it; v. 17). The pasture, however, dries up, and the water level sinks, prompting a long and exhausting trek to new grazing. Shortly before daybreak, the herd at last reaches water and drinks (v. 20-28a), but then is surprised by a hunter who rains deadly arrows down on them (v. 28a-35).

It should be noted that in one edition of the Hudhali diwan, an additional verse precedes paragraph B. It describes a mountain goat that cannot save itself from death. The verse reads:

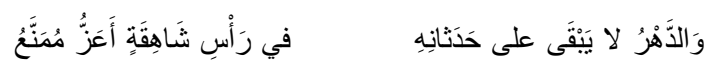

Nothing remains of the days, not even a strong and protected [mountain goat] on the peaks of a high mountain. ${ }^{12}$

The authenticity of this verse as a true part of the 'ayniyya is, however, doubtful. First, this version of the diwan is not, as the editors point out in the introduction $(\mathrm{c}-\mathrm{d})$, the original, authentic version of al-Sukkari's collection. Second, contrary to the natural structure of the 'ayniyya in which the story of the defeated creature is described in detail, its tale in this additional paragraph is very brief. Finally, this is the sole source with the additional verse.

The onager episode is followed by one that concerns an oryx (C; v. 36-48), living in constant fear, always alert for huntsmen and their hounds, its ears ever straining to pick up danger (v. 36-39). Two verses $(37,39)$ from this scene read:
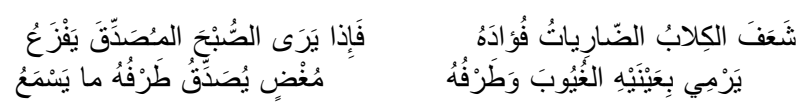

The well-trained dogs have brought terror to its heart; when it sees the coming of true dawn, it is fearful.

It casts its glance to the horizon, glimpsing with half-closed eyes, and what it sees confirms what it hears.

With nightfall, tension eases a little for the oryx, but it cannot escape the rain and icy winds to which it is exposed (v. 38). The day following, the animal's fears are realized when it falls prey to a hunter and his hounds (v. 40-47). Sensing their voices, the beast flees, but cannot shake free of the three dogs in pursuit. It turns and stands to fight, driving its sharp horns into their bodies, but it has no chance. The hunter raises his bow and fells the oryx with his arrows. Verse 48 describes the great slaughtered beast falling to the ground.

The third episode (D) tells of two brave, undefeated warriors fighting on opposite sides of a great battle (v. 49-63). As it opens, we see them at their full strength moments before combat, glorious in their

\footnotetext{
${ }^{11}$ Albert Arazi, "Le Thrène d'Abu Du’ayb ou La Mort Dépoetisée," in Festschrift Ewald Wagner zum 65. Geburtstag, Band 2: Studien zur arabischen Dichtung, ed. Wolfhart Heinrichs and Gregor Schoeler (Beirut: In Kommision bei Franz Steiner, Verlag Stuttgart, 1994), 72-89; Jones, Early Arabic Poetry, 493-524.

${ }^{12}$ Muhammad Mahmud al-Shinqiti, ed., Diwan al-Hudhaliyyin (Cairo: al-Dar al-Qawmiyya li-l-Tiba'a wa-l-Nashr, 1965$), 4$.
} 
shining armor, astride their noble steeds (v. 49-56, 59-61). The poem moves on to narrate the clash between them (v. 57-58, 62). Each unbowed warrior is confident of his own strength, weapons, and fighting skills, but each now tears apart his adversary, turning his enemy's body into "a red garment that will never be repaired" (v. 62). Verse 63 ends the poem, expressing the loss that befell each warrior:

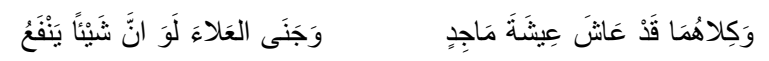

Each of them had lived the life of man who had attained glory and had garnered eminence-if anything were of avail against fate.

To recap, the macrostructure of Abu Dhu'ayb's 'ayniyya consists of an introduction (A), followed by three episodes (B, C, and D). In my breakdown of the structure of each episode, I use the terms functional unit, paragraph, and secondary paragraph, as outlined in my 2005 article on the division of the classical Arabic qasida. ${ }^{13}$ In another study, published a year earlier (2004), I discussed in detail the main approaches of classical and modern critics to the structure of the classical Arabic qasida. ${ }^{14}$ For the purpose of the present study, there is no need to detail these other approaches, which are clearly described in the 2004 article. I claim that these methods fail to demonstrate sufficient understanding of the poetic text. In the 2005 article, I offer another approach to analyzing the classical Arabic poem's structure. New structural sections are consequently highlighted in the text here. I suggest that dividing the poem according to these sections provides a more accurate correlation with the poem's content. It also may reveal new aspects and original elements missed by the other approaches. I use the terminology mentioned above: the functional unit, paragraph, and secondary paragraph. The first is a verse-cluster with a specific aim or purpose of the poem. This long 'ayniyya is a single functional unit, all of its four parts articulating the powerlessness of the individual (human or animal) to defy fate. The paragraph is a division within the functional unit, describing the unit's precise topics or focuses. In this poem, each of the four parts can be considered a paragraph. The secondary paragraphs are mini-sections within the paragraphs.

The paragraph that constitutes the poem's introduction or prelude contains two principal secondary paragraphs, one depicting the bereaved father $\left(A_{1}\right)$, and the other addressing the implacability of fate $\left(A_{2}\right)$. The opening $\left(A_{1}\right)$ describes the suffering and grief of a father (the poet-protagonist) whose sons have perished (v. 1-8); then moves on to the overwhelming force of fate $\left(A_{2}\right)$, which renders useless every effort made by a father to protect his sons (v. 9-10). The poem then returns to the desolation of the bereaved parent, his bottomless sorrow, along with his attempt to pretend strength and indifference in the face of envious eyes (v. 11-13). The paragraph's final verse (v. 14) gives profound expression to the supremacy of fate:

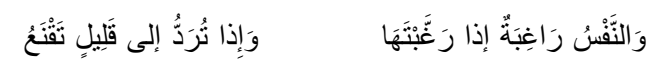

The soul wants much when you cause it to want much; but when it is brought back to little, it is content.

With the two secondary paragraphs circling within this first paragraph, its structure is defined as cyclical. It can be summarized as shown in Figure 1.

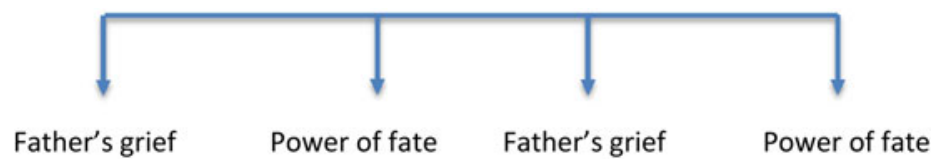

Figure 1. Introduction/prelude (A).

\footnotetext{
${ }^{13}$ Ali Hussein, "An Analytical Division of the Old Arabic Poem: A Suggestion for a New Method of Dividing and Analyzing the Old Arabic Poem with Applications to a Text by Hassan b. Thabit," Journal of Arabic Literature 36, no. 1 (2005): 74-102.

${ }^{14}$ Ali Hussein, "Classical and Modern Approaches in Dividing the Old Arabic Poem," Journal of Arabic Literature 35, no. 3 (2004): 297-328.
} 
The second paragraph features the episode of the onagers (B), which is related in four secondary paragraphs. It first describes the good life lived by the onagers $\left(B_{1} ; \mathrm{v} .15-19\right)$; then their departure in search of new grazing $B_{2}$; v. 20-28a); followed by the hunter's assault on the herd ( $B_{3}$; v. 28a-33); and finally the state of the animals in the aftermath of the hunt $\left(\mathrm{B}_{4} ; \mathrm{v} .34-35\right)$. The paragraph's internal structure is serial, its secondary paragraphs chronologically arranged, as Figure 2 shows.

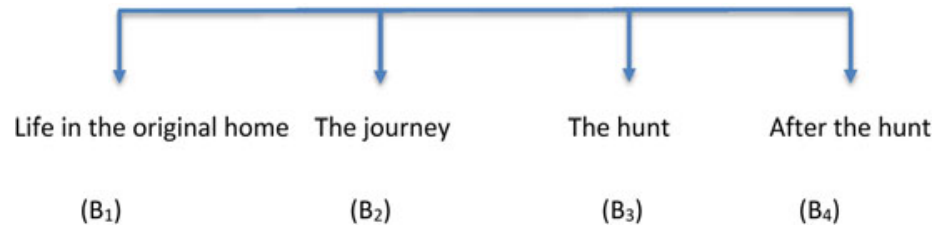

Figure 2. Episode of the onagers (B).

The episode of the oryx $(\mathrm{C})$ is narrated in three secondary paragraphs: the life of the oryx before the hunt $\left(\mathrm{C}_{1}\right)$; the hunt $\left(\mathrm{C}_{2}\right)$; and the fate of the oryx in its aftermath $\left(\mathrm{C}_{3}\right)$. In $\mathrm{C}_{1}$, the oryx is fearful and cautious (v. 36-39); in $C_{2}$, the oryx is set upon by the hounds (v. 40-47); and the paragraph ends with the bringing down of the oryx, a creature the size of a camel, its body pierced by a spear (v. 48). As in the episode of the onagers, the paragraph's internal structure is serial (Fig. 3).

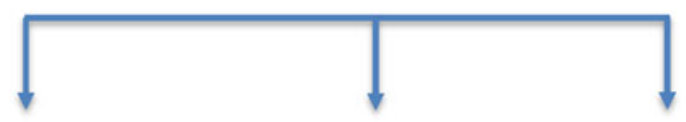

\section{Life before the hunt The hunt The oryx after the hunt}
$\left(C_{1}\right)$
$\left(C_{2}\right)$
$\left(\mathrm{C}_{3}\right)$

Figure 3. Episode of the oryx (C).

The poem's final paragraph, the episode of the warriors $(\mathrm{D})$, is made up of five secondary paragraphs. The first describes the two warriors ready for battle, both of them armed, skillful, and clad in gleaming armor $\left(D_{1}\right.$; v. 49-56); and the second tells of the fierce combat between them $\left(D_{2} ;\right.$ v. 57-58). The poem then returns to describing their armor $\left(D_{1}\right.$; v. 59-61); before resuming its account of their battle $\left(D_{2}\right.$; v. 62). The fifth and closing paragraph hints at the destiny of the warriors after their bloody fight $\left(\mathrm{D}_{3}\right.$; v. 63). The structure of this paragraph is cyclical, similar to the Introduction (Fig. 4).

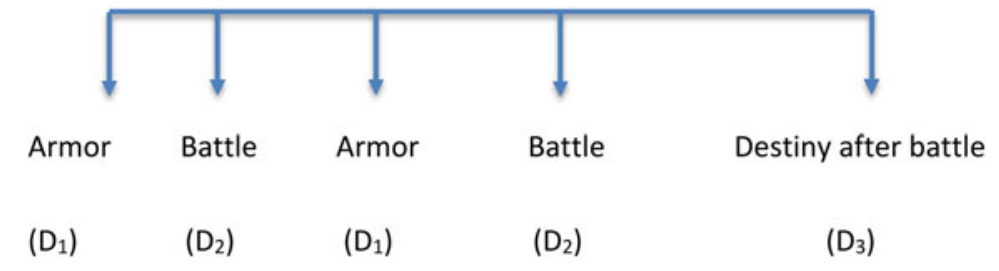

Figure 4. Epsiode of the warriors (D).

The internal structure of the poem, as a whole, can be summarized as follows:

$A_{1}-A_{2}-A_{1}-A_{2}$ (introduction, cyclical)

$\mathrm{B}_{1}-\mathrm{B}_{2}-\mathrm{B}_{3}-\mathrm{B}_{4}$ (episode of the onagers, serial)

$\mathrm{C}_{1}-\mathrm{C}_{2}-\mathrm{C}_{3}$ (episode of the oryx, serial)

$\mathrm{D}_{1}-\mathrm{D}_{2}-\mathrm{D}_{1}-\mathrm{D}_{2}-\mathrm{D}_{3}$ (episode of the warriors, cyclical).

There are unmistakable similarities between this famed poem by Abu Dhu'ayb and two poems composed by Saida b. Ju'ayya (Poem 2, with basit t meter, $m$ as a rhyming letter, and forty-six verses; and 
Poem 4, with wâfir meter, lām as a rhyming letter, and twenty-three verses). ${ }^{15}$ These resemblances are in the content, the function and, most importantly, the structure of the poems.

Little is known of Sa'ida b. Ju'ayya, other than that his rāwiya (the transmitter of his poems) was Abu Dhu'ayb. ${ }^{16}$ Some consider him a pre-Islamic poet, and others a mukhadram, who converted to Islam but never met the Prophet Muhammad. ${ }^{17}$ These two opinions can perhaps be reconciled: Sa ida spent most of his life in the Jahiliyya (pre-Islamic era), but lived to witness the birth of Islam and died shortly afterward. He can therefore correctly be considered a pre-Islamic poet and equally correctly a mukhadram.

Poem 2 of Sa ida has the same function as Abu Dhu'ayb's 'ayniyya: proving that nothing can defeat time and its two intimate partners, fate and death. In both poems the notion of pre-Islamic time prevails: it is the negative power that brings annihilation to every creature, no matter its strength. ${ }^{18}$ The poem's macrostructure, too, resembles that of Abu Dhu'ayb's poem. An introduction (A) about the invincibility of time (v. 1-7) is followed by three paragraphs that illustrate the concept: a tale of a mountain goat (B; v. 8-16); followed by that of an antelope herd (C; v. 17-27); and lastly the story of a tribe (D; v. 28-46). Again like Abu Dhu'ayb, the central characters in each episode are more powerful than those in the preceding episode. Abu Dhu'ayb's oryx, which has horns to defend itself, is stronger than his onagers, and his lethal, armored warriors are stronger than the oryx. ${ }^{19}$ In Sa ida's poem, the lonely mountain goat is more vulnerable than the antelope herd, which is, in turn, weaker than the tribesmen. Both poems show time defeating increasingly formidable foes. In both, there is an introduction followed by three storiestwo about animals, one about people-all of them demonstrating the inexorable force of time. This is intended to console: the poet-protagonist has experienced a harsh and sorrowful fate, but it is simply the nature of time, which is harder on the strong than on the weak.

Whereas Abu Dhu'ayb's introduction is about the death of sons, Sa ida's concerns aging. Once a powerful youth, he has been turned into a frail old man by time. He wonders whether old age can be escaped (v. 1). He describes grey hair as an untreated illness (v. 2), and how the aged always look weary, their

\footnotetext{
${ }^{15}$ Al-Sukkari, Kitab, 1122-38.

${ }^{16}$ Al-Qadi al-Jurjani, al-Wasata bayan al-Mutanabbi wa-Khusumih, ed. Muhammad Abu al-Fadl Ibrahim and 'Ali Muhammad al-Bijawi (Egypt: Matba'at 'Isa al-Babi al-Halabi, 1966[?]), 16; Ibn Qutayba, al-Shi'r wa-l-Shu'ara' (Cairo: Dar al-Hadith, 2002), 639. See also E. Bräunlich, "Versuch einer literargeschichtlichen Betrachtungsweise altarabischer Poesien," Der Islam 24 (1937): 220, 222.

${ }^{17}$ The term mukhadam is used here in its simplest definition: a poet who lived in both eras (pre-Islamic and early Islamic) regardless of his poetic output, in contrast to one who lived in both eras whose poetry under Islam differs in structure and content from the Jahili poetry. The differences between poems composed by mukhadram poets during the two eras is, of course, interesting and has been discussed by scholars such as Akiko Motoyoshi Sumi, Description in Classical Arabic Poetry: Wasf, Ekphrasis, and Interarts Theory (Leiden: Brill, 2004), 61-91; and Jaroslav Stetkevych, "A Qasidah by Ibn Muqbil: The Deeper Reaches of Lyricism and Experience in a Mukhadram Poem; An Essay in Three Steps," Journal of Arabic Literature 37, no. 3 (2006): 303-54. For further insights see Renate Jacobi, "The 'Khayal' Motif in Early Arabic Poetry," Oriens 32 (1990): 50-64; Renate Jacobi, "Mukhadram," The Encyclopaedia of Islam, 7: 516; Jennifer Hill Boutz, "Hassan ibn Thabit, A True Mukhadram: A Study of the Ghassanid Odes of Hassan ibn Thabit" (PhD diss., Georgetown University, 2009); and Werner Diem, Studien zu Überlieferung und Intertextualität der altarabischen Dichtung. Das Mantelgedicht Ka`b ibn Zuhayrs (Wiesbaden: Harrassowitz Verlag, 2010), 18-28.

Identification of Sa ida b. Ju'ayya as a pre-Islamic poet is based mainly on Abu al-Qasim al-Hasan b. Bishr al-Amidi, al-Mu'talif wa-l-Mukhtaliffi Asma' al-Shu'ara' wa-Kunahum wa-Alqabihim wa-Ansabihim wa-Ba'di Shi'rihim, ed. Fritz Krenkow (Beirut: Dar al-Jil, 1991), 103. Among those who believe Sacida to have been a mukhadram are Abu 'Ubayd 'Abd Allah b. 'Abd al-'Aziz b. Muhammad al-Bakri al-Andalusi, Simt al-La'ali fi Sharh Amali al-Qali, ed. 'Abd al-'Aziz al-Maymani (Beirut: Dar al-Kutub al-'Tlmiyya, 1935[?]), 115; Hajji Khalifa Mustafa b. 'Abd Allah, Kashf al-Zunun 'an Asami al-Kutub wa-l-Funun (Baghdad: Maktabat al-Muthanna, 1941), 791; and Ibn Nur al-Din Muhammad b. 'Ali, Taysir al-Bayan li-Ahkam al-Qur'an, ed. 'Abd al-Mu'in al-Hursh (Syria: Dar al-Nawadir, 2012), 333. A discussion of the two opinions is found in 'Abd al-Qadir b. 'Umar al-Baghdadi, Khizanat al-Adab wa-Lubb Lubab Lisan al-'Arab, ed. 'Abd al-Salam Muhammad Harun (Cairo: Maktabat al-Khanji, 1997), 85-86. See also Joseph Hell, "Der Islam und die Hudailitendichtungen," in Festschrift Georg Jacob zum siebzigsten Geburtstag, ed. Theodor Menzel (Leipzig: Otto Harrassowitz, 1932), 82; and Fuat Sezgin, Geschichte des arabischen Schrifttums (Leiden: E. J. Brill, 1967-1984), 259.

${ }^{18}$ This notion of jähilite (pre-Islamic) time (dahr) is described and satirized in the Qur'an, 45:24. See an explanation of this notion in Jar Allah al-Zamakhshari, al-Kashshaf 'an Haqa'iq Ghawamid al-Tanzil (Beirut: Dar al-Kitab al-'Arabi, 1986), 291. For more on philosophical notions of fate in Hudhali poetry, including that of Saida and Abu Dhu'ayb, see Muhammad Ahmad Bariri, al-Uslubiyya wa-l-Taqalid al-Shi'riyya. Dirasa fi Shi'r al-Hudhaliyyin (Cairo: 'Ayn li-l-Dirasat wa-1-Buhuth al-Insaniyya wa-l-Ijtima iyya, 1995), 38-96. See also 'Atif Muhammad Kan'an, Falsafat al-Mawt fi Qasidat al-Ritha' 'inda Shu'ara' Hudhayl: Sakhr al-Ghayy Namudhajan (Amman, Jordan: University of Petra, 2007).

${ }^{19}$ Arazi, "Thrène," 88-89.
} 
shoulders, back, and joints aching (v. 3-4). Year round, even on summer's hottest days, he suffers from cold (v. 5). He is neglected, abandoned behind the tent, addressed only when the tribe prepares to migrate, when he is ordered to look sharp and prepare himself for departure. He stands with difficulty, leaning heavily on a stick that he grasps in a shaking hand, drained, trembling, and sluggish (v. 6-7). The entire introduction focuses on advanced age, with no clear secondary paragraphs.

In the three paragraphs that follow, each opens with a phrase describing the dominance of time, as do those of Abu Dhu'ayb's 'ayniyya. The episode of the mountain goat begins, تاللَّهِ يَيََْى عَلى الأَيَّام (v. 8, By God, none can guard his life against Time, even...). That of the antelope herd opens with cating that even the antelope cannot protect themselves against time. The phrase that begins the last epi-

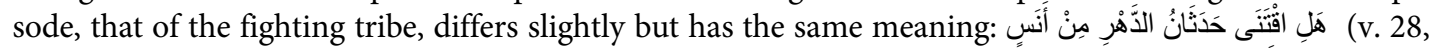
Do the accidents of Time spare those [people]?) This final phrase includes the words حَثنان الدَّهُ (1) the expression used in the opening phrases of the last three paragraphs in Abu Dhu'ayb's elegy. The sole structural difference between the poems of Sa ida and Abu Dhu'ayb is that the latter retains the same phrasing in the opening of each of his three paragraphs, whereas Sa ida alters it.

The repetition of the expression حََنَانُ الدَّهْ seems to be a matter of poetic intertextuality rather than simply a formulaic expression to help the poet or the poem-reciter remember the text. Modern scholars believe that pre- and early Islamic poetry was oral-formulaic, which sometimes forced on poets forms necessary for mnemonics. ${ }^{20}$ Opening all three paragraphs of the cayniyya with the same phrase does not, however, necessarily suggest that the poem was orally improvised. Two types of oral composition must be distinguished: one, a pure oral composition; the other, more sophisticated. In the first, the poet improvises his poem rapidly and spontaneously. Such poems are usually short, with evidence indicating that they have been quickly composed-such as repetition of a certain phrase at the beginning of some verses. This kind of

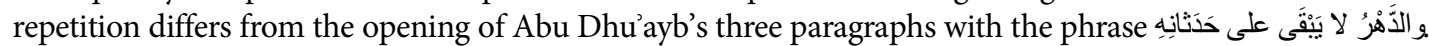
In purely improvised poems, almost every verse begins with the same phrase, which is not the case in Abu Dhu'ayb's 'ayniyya. The other type of oral composition is produced when a poet composes several verses of his poem, considers them, then later creates more verses, continuing in this way until the poem is complete. This latter type of composition, which is longer and structurally more complicated, is arguably not purely oral. Abu Dhu'ayb's 'ayniyya, by the nature of its complex structure (as analyzed above), seems to be this second type, but it would take a separate study to be definitive. Opening each of the three paragraphs with the aforementioned leitmotif is not, therefore, a device to preserve the oral text stylistically and structurally, but a means of weaving the poem's different parts together to serve its main theme. ${ }^{21}$ This premise is supported by Albert Arazi, who believes that repeating the same phrase is a technique that enables rapid recognition of the poem's structure, and informs the reader or listener that the three paragraphs opening with this phrase have the same function. ${ }^{22}$ In my view, a poem with clear demarcation between its different themes, accompanied by a means of connecting them (such as the phrase used by Abu Dhu'ayb) indicates a more sophisticated-or, at least, more ordered-and consequently newer structure than that of similar poems whose demarcations and connections are blurred (unless this is modern or very late poetry, in which the poetic concept has totally changed). Jacobi's study of the development of the multi-themed qasida may support this premise. According to Jacobi, the qasida form began by merging different themes with no clear connection between them (whereas, normally, poets jumped unexpectedly from one theme to another). This became poetry that encompassed different themes, elegantly connected. Poets once thought of genuine ways to connect the divergent themes in their poems. ${ }^{23}$

\footnotetext{
${ }^{20}$ Ignaz Goldziher, “Bemerkungen zur arabischen Trauerpoesie,” Wiener Zeitschrift für die Kunde des Morgenlandes 16 (1902): 307-39. For the oral tradition of pre-Islamic poetry, see also James T. Monroe, “Oral Composition in Pre-Islamic Poetry," Journal of Arabic Literature 3 (1972): 1-53. Suzanne Stetkevych assumes that the use of rhetoric in general, not only repetition, was a mnemonic that poets used to serve and preserve oral poetry. See "From Jahiliyyah to Badiiiyyah: Orality, Literacy, and the Transformations of Rhetoric in Arabic Poetry," Oral Tradition 25, no. 1 (2010): 211-14.

${ }^{21}$ See a hint of these two types of oral composition in Ali Ahmad Hussein, "The Rise and Decline of Naqa'id Poetry," Jerusalem Studies in Arabic and Islam 38 (2011): 323-41. These two types of oral composition of classical Arabic poetry deserve in-depth examination in separate studies.

${ }^{22}$ Arazi, “Thrène," 88-89.

${ }^{23}$ Renate Jacobi, "The Origins of the Qasida Form," in Qasida Poetry in Islamic Asian and Africa, ed. Stefan Sperl and Christopher Shackle, Classical Traditions and Modern Meanings (Leiden: E. J. Brill, 1996), 1: 21-34.
} 
Once the introduction to Sa ida's poem ends, the mountain goat episode follows (v. 8-16). This episode has three secondary paragraphs: first a description of the goat's life before the hunter's attack $\left(\mathrm{B}_{1}\right.$; v. 8-11, 13-14); followed by the hunt $\left(B_{2} ;\right.$ v. 12,15$)$; and last the consequences for the mountain goat of the attack $\left(B_{3} ;\right.$ v. 16). The internal structure of this paragraph is $\left(B_{1}\right)-\left(B_{2}\right)-\left(B_{1}\right)-\left(B_{2}\right)-\left(B_{3}\right)$ : in its life prior to the hunt, the mountain goat enjoys a strong body, and lives atop mountains where food is plentiful and human beings scarce (v. 8-10). Like Abu Dhu'ayb's oryx, the goat is a cautious creature, experiencing moments of acute anxiety, looking continually toward the trees in fear that a hunter may emerge at any moment (v. 11). This narrative of the goat's existence is interrupted to describe the hunter, with his bow and razor-sharp arrows, who is predestined to kill the goat (v. 12). The poem then returns to the goat, looking vigilantly toward the trees until the sun sets, when he approaches them for food, believing himself safe (v. 13-14). At exactly that moment, the hunter surprises the creature with a hail of arrows (v. 15). At this point, the poem moves to another secondary paragraph, which relates the mountain goat's attempt to escape the hunter, unaware that a lethal arrow has pierced its flesh. Within moments, the goat falls dead to the ground (v. 16). The paragraph's structure is similar to that of Abu Dhu'ayb's warrior episode, and is summarized in Figure 5.

Life before The hunt Life before The hunt After the hunt
the hunt
the hunt

$\left(B_{1}\right)$

$\left(B_{2}\right)$

$\left(B_{3}\right)$

Figure 5. Episode of the mountain goat (B).

The antelope episode has same serial structure and components as that of Abu Dhu'ayb's onager paragraph. As in the cayniyya, it contains four secondary paragraphs: the life of the herd prior to the hunt $\left(C_{1}\right.$; v. 17-19); the herd approaching a new water source $\left(C_{2}\right.$; v. 20-23); the hunt $\left(C_{3}\right.$; v. 24-26a); and the herd in its aftermath $\left(C_{4} ;\right.$ v. 26b-27). The paragraph's internal structure is $C_{1}-C_{2}-C_{3}-C_{4}$ (Fig. 6).

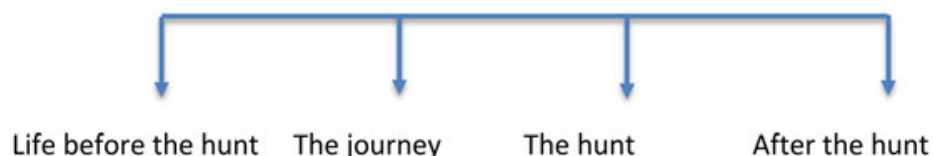

$\left(C_{1}\right)$

$\left(C_{2}\right)$

$\left(C_{3}\right)$

$\left(\mathrm{C}_{4}\right)$

Figure 6. Episode of the antelope herd (C).

The first secondary paragraph $\left(\mathrm{C}_{1}\right)$ pictures the herd: a group of white antelope, resembling strung white pearls, the wind blowing across their withers, making their coats look combed (v. 17). As the pasture dries up, however, so do their bodies (v. 18-19). In the next secondary paragraph $\left(\mathrm{C}_{2}\right)$, the antelopes look to the horizon for flashes of lightning (v. 20-22). Once sighted, they joyously make their way toward it, expecting to find rainfall (v. 20b). They travel through the night, reaching water while it is still dark (v. 23). In the morning, they are surprised by a hunter with a long, sharp spear $\left(\mathrm{C}_{4} ; \mathrm{v}\right.$. 24-26a). He attacks, and the herd sinks in blood $\left(\mathrm{C}_{4}\right.$; v. 26b-27).

The final part of Sa'ida's poem (D) has three secondary paragraphs. The first is about the life of the tribe $\left(D_{1}\right)$; the second about the battle $\left(D_{2}\right)$; and the poem ends with the tribe's fate following the battle $\left(D_{3}\right)$. When he describes the tribe $\left(D_{1}\right)$, Sa ida stresses its multitude. When its members are gathered together, it is the size of a mighty mountain. Their home is Macyat (v. 28-29), which Abu 'Ubayd al-Bakri, an Andalusian Arab geographer (d. 1094) variously identifies as an oasis belonging to the 
Kinana or the Muzayna tribes. It was, he adds, the site of a battle against the Hudhayl. ${ }^{24}$ The tribe is served by a talented spy, Ibn Ju'shum, who gathers vital intelligence (v. 30). He is praised for his loyalty to the tribe, his courage and his strength, and likened to a lion, crouching concealed in a wood, awaiting its prey (v. 31-32). This man, says al-Sukkari, is Suraqa b. Malik b. Ju'shum. ${ }^{25}$ If this is who Sa'ida means, he was a member of the Kinana and a comrade $(s a h \bar{a} b a)$ of the Prophet Muhammad, who lived in al-Qudayd close to Mecca and died in 645. Before converting to Islam, he was a strident enemy of the Prophet, and did not become Muslim until after the conquest of Mecca and siege of al-Ta'if in $630 .^{26}$

Because of their first-rate intelligence and their vast numbers, the tribe has total confidence in its strength and ability to protect itself and its way of life. In verse 33, Sa ida reveals that the tribe is one of the hums, a group of pre-Islamic cultic, pietist communities, which included the Quraysh and Kinana. ${ }^{27}$ Since it appears that Ibn Ju 'shum is from the Kinana, it is possible that this is the tribe featured in the poem. If so, the battle against Muslim troops would have taken place prior to 630. Because the poet laments the fall of the Kinana and it is known that his Hudhayl tribe converted to Islam only in 630, it is clear that the poem dates from before these events, making it a jähilite (pre-Islamic) poem, composed in 630 at the latest. ${ }^{28}$

In the next secondary paragraph $\left(\mathrm{D}_{2}\right)$, the poem continues its account of the sudden enemy attack (v. 33b-38, 45). If this is, in fact, the battle suggested above, the enemy is made up of Muslim horsemen on armored, battle-hardened, and fleet mounts (v. 34-35). The two sides exchange spear- and sword-thrusts, each endeavoring to force the other to drink from the cup of death (v. 36-38).

The secondary paragraph that follows $\left(\mathrm{D}_{3}\right)$ depicts the defeated tribe after the battle: the warriors wounded and dead, their bodies scattered across the battlefield (v. 39-44, 46). The injured suffer in both body and soul, many of them crying out. The dead lie covered in blood. The tribe's women have been abducted: some on horseback, some on foot, they trail their captors, weeping as they approach enemy land. Their ripped clothes are a sad reminder of the beautiful garments in which they were once clad (v. 39-44). The poem then suddenly backtracks to describe the attack $\left(\mathrm{D}_{2} ; \mathrm{v} .45\right)$. It ends $\left(D_{3}\right.$; v. 46) with a description of the captives and booty. With this sudden shift, the structure of the paragraph is cyclical (Fig. 7).

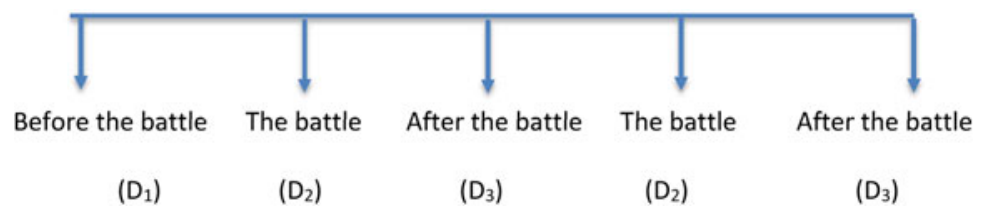

Figure 7. Episode of the fighting tribe (C).

Figure 8 and the paragraph following detail the structural similarities and discrepancies between this poem and that of Abu Dhu'ayb.

To summarize, Abu Dhu'ayb begins and ends his poem with cyclically structured paragraphs, using a serial structure for those in between. Significantly, he adopts the principal structures of two paragraphs of Sa ida's poem: he uses the serial structure of the antelopes to shape his episode of the onagers, and, to some degree, that of the oryx; and he takes Saida's mountain goat structure (and to some degree his

\footnotetext{
${ }^{24} \mathrm{Abu}$ 'Ubayd Allah 'Abd Allah al-Bakri, Mu'jam ma Sta'jam min Asma' al-Bilad wa-l-Mawadi (Beirut: 'Alam al-Kutub, 1982), 334, 1246. Yaqut al-Hamawi (d. 1209) mentions that it was a place name; see his Mújam al-Buldan (Beirut: Dar Sadir, 1995), 160.

${ }^{25}$ Al-Sukkari, Kitab, 1132.

${ }^{26}$ Husayn, al-Shakl wa-l-Madmun, 76-77; 76 n. 18 references. See also Wim Raven, "Hijra," The Encyclopaedia of Islam, Three, https://referenceworks.brillonline.com/browse/encyclopaedia-of-islam-3.

${ }^{27}$ Harry Munt, "Hums," The Encyclopaedia of Islam, Three, https://referenceworks.brillonline.com/browse/encyclopaedia-of-islam-3.

${ }^{28 c} \mathrm{Abd}$ al-Qadir al-Baghdadi (d. 1682) is among several classical scholars who understand the poem as an elegy to the poet's lost tribe. See Khizanat al-Adab, 161. See also a similar note in Jalal al-Din al-Suyuti, Sharh Shawahid al-Mughni, ed. Ahmad Zafir Kujan (Lajnat al-Turath al-'Arabi, 1966), 156.
} 


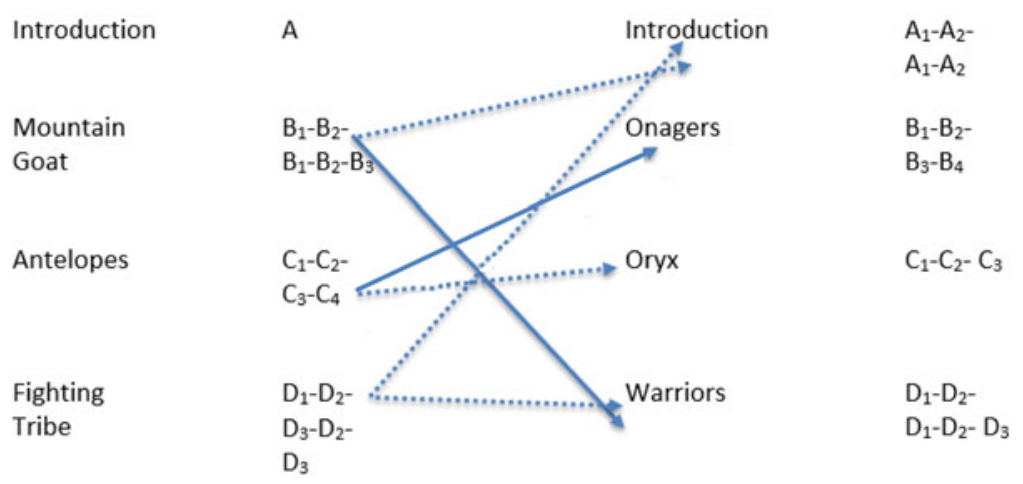

Figure 8. Structural comparison of Abu Dhu'ayb's 'ayniyya and Sa'ida's Poem 2

tribe structure) to tell his story of the warriors. The structure of his introduction is virtually identical to the episode of the mountain goat, with one secondary paragraph less. It should be noted that the structures of the 'ayniyya and Sa ida' poem are not in the normal style of either poet. The style differs from other poems in their diwans.

However, Sa'ida's diwan does include a second poem (Poem 4) with functional and structural similarities to the two poems above. ${ }^{29}$ It runs twenty-three verses and has three main paragraphs. This poem opens with two verses describing the advanced years of the poet-protagonist (A). Through his conversation with a woman named Umama, his deteriorating physical appearance is revealed. Umama expresses her distress that he has become an inconvenience and a burden to his tribe. What he is experiencing should happen only to those who hate him, she exhorts. The first of these two opening verses reads:

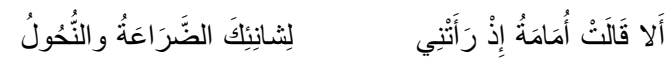

Umama said, when she saw me: “To your enemies, this humility and weariness!”

A very similar conversation is found in Abu Dhu'ayb's 'ayniyya. The phrase, قَالَتْ أُمَيْنَة, echoes Saida's almost identical قَالَتْ أُمَامَة. Umama appears also in its diminutive form, Umayma, in Sa ida’s poem (v. 3, 4, 13). That is, the same woman describes the poet-protagonist's physical debilitation in both poems. The conversation in Abu Dhu'ayb's poem begins:

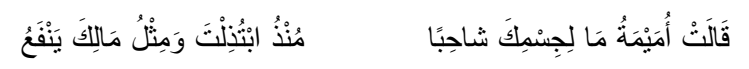

Umayma said, "What is wrong with your body that you are so haggard since you ceased to look after yourself, when wealth such as you have could help you?"

The dialogue with the woman is one of the techniques used in classical Arabic poetry to reveal the

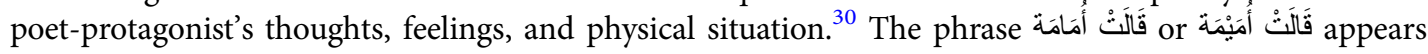
in other pre-Islamic and Islamic poems, and is considered a formula (a fixed phrase), like many other formulas used by classical Arab poets in their canon. ${ }^{31}$ The use of this specific formula in Sa ida and

\footnotetext{
${ }^{29}$ Al-Sukkari, Kitab, 1142-50.

${ }^{30}$ Arazi, “Thrène," 84.

${ }^{31}$ See "qālat Umamatu," for example, in Ibn Manzur Jamal al-Din, Lisan al-'Arab (Beirut: Dar Sadir, 1993), 535; and al-Jahiz 'Amr b. Bahr, al-Bayan wa-l-Tabyin (Beirut: Dar wa-Maktabat al-Hilal, 2002), 161. See "qālat Umaymatu" in Kamal al-Din al-Anbari, al-Insaf fi Masa'il al-Khilaf Bayn al-Nahwiyyin al-Basriyyin wa-l-Kufiyyin (al-Maktaba al-'Asriyya, 2003), 407. For
} 
Abu Dhu'ayb's two poems, however, seems more than coincidental, particularly when taken together with other intertextual relationships of the two texts, as described below.

In Sa ida's poem, the poet-protagonist's reply comprises two main paragraphs: one of self-praise (B; v. 3-7) and the other acknowledging the brutality of time or fate (C; v. 8-23). The aim of both is to console. The self-praise can be summarized as: "Although I'm old, I'm still useful." Its main motifs are that the little time that remains can be profitably spent (v. 3): others, of every status, still seek his advice and help (v. 4); his honor and reputation are intact; and he does not slander his friends (v. 6). A further motif of praise is his pride in his tribe and his ancestors (v. 7).

Following this, the poet-protagonist dwells on the dominion of time, fate, and death. His main message here is that he is not to blame. It is time which has made him age, and no one is free of this fate. This theme is given direct expression in a story about a rich and powerful man who cannot keep death away. The paragraph's internal structure recalls the macrostructure of the two previous poems, both of which are built of an introduction followed by three further paragraphs. Here, the story is introduced by a single verse, which can be considered a short introduction to the paragraph as a whole. This verse $\left(\mathrm{C}_{2} ;\right.$ v. 8$)$ expresses that no one escapes death:

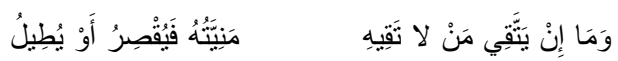

None can protect himself when Death comes for him, whether his life is long or short.

To illustrate the pitiless cruelty of death, the poem presents an affluent family man whose assets include large herds of camel $\left(\mathrm{C}_{2} ;\right.$ v. 9-11). A description of his wealth is followed by that of the grave in which he will lie $\left(\mathrm{C}_{3}\right.$; v. 12-18), a grave that will fall prey to a hyena, which will dig up his body as a tasty meal. ${ }^{32}$ The poem ends with a portrayal of a mountain goat $\left(\mathrm{C}_{3} ; \mathrm{v} .19-23\right)$. In contrast to the mountain goat in Poem 2, Sa ida here uses the animal to show that the rich no more escape death than anyone else, even if they flee to the remote peaks inhabited only by the mountain goat. Only goats can reach these mist-shrouded, wind-blasted summits (v. 19-20). The rains flow down their slick slopes to the foothills below like the blood flowing from the neck of a slaughtered camel. The peaks are as slippery as the bodies of wet nightjars (v. 21-22). Even if, against all odds, an individual reaches the mountain summit, death or fate will find him there (v. 23).

Taken as a whole, the poem's structure calls to mind a specific form of the multi-themed qasida, which opens with a lament for the poet-protagonist's lost youth, followed by paragraphs that attempt to console. ${ }^{33}$ Solace often consists of the poet-protagonist recalling his past glory. In Sa ida's poem, however, the aged protagonist comforts himself not by recalling the past, but by attempting to convince the maiden, Umama (and, more importantly, himself) that he is still useful, and that no man can overcome time. The poem in this way is multi-thematic. Only the second attempt at self-consolation has a similar macrostructure to the other two poems considered in this article.

Abu Dhu'ayb adapted the structure of his teacher's Poem 2 and also was influenced by Sa ida's Poem 4 (principally the conversation with Umayma), constructing a poem of his own that is more complicated than either of his two sources. It is almost the length of Sa ida's two poems combined (sixty-three verses compared with sixty-nine in Sa ida's two poems); its beginning and end are cyclical, with the serial structure relegated to the middle of the poem; and the phrases that Saida uses at the start of each paragraph are enhanced. Abu Dhu'ayb has created a poem that is structurally more organized than either of the two written by Saida.

It should be noted that a third poem by Saida (Poem 8) eulogizes a son who dies. It ends with two brief stories describing the death of animals: a mountain goat (six verses) and an oryx (only two verses),

the formulas in classical Arabic poetry, see Thomas Bauer, "Formel und Zitat. Zwei Spielarten von Intertextualität in der altarabischen Dichtung," Journal of Arabic Literature 24, no. 2 (1993): 117-38; and Diem, Studien zu Überlieferung, 158-69.

${ }^{32}$ Albert Arazi, "Le Mesonge Admirable. Étude sur le genre descriptif dans la poésie arabe médiévale; I. La description préislamique," Jerusalem Studies in Arabic and Islam 23 (1999): 21, n. 62.

${ }^{33}$ See Poem 16 by al-Marrar b. Munqidh (d. 718) in al-Dabbi, The Mufaddaliyat, 142-59. 
but its structure and content are less reflected in Abu Dhu'ayb's 'ayniyya than the two poems discussed above. Poem 8 was possibly composed later, after Sa ida wrote Poem 2. Supporting this assumption is the incomplete telling of the story of the oryx in Poem 8, with only the animal's pre-hunt life related. Sa ida's audience may have been familiar with the animal's complete story from his earlier two poems, and there was no need to retell it in full. ${ }^{34}$

These poems by Sa ida and Abu Dhu'ayb deviate from the structural norm of the pre-Islamic and early Islamic elegy. Since this genre was originally composed to be performed as a funeral ritual, it often had a loose or at least noncomplex structure. It was usually a short text expressing the feelings of a relative-poet or, more often, poetess, and lauding the attributes of the deceased, as well as, sometimes, calling for revenge on his murderers. ${ }^{35}$ The use of the animal hunt in the elegy, or in a poem describing the power of fate, was far rarer. Jacobi considers a structure incorporating animal hunting scenes purely Hudhalian. She sees Sa'ida b. Ju'ayya as an originator of this structure. ${ }^{36}$ Muhammad Ahmad Bariri's view is similar, but he considers the structure an innovation that was not specifically Sa'ida's, but belonged to Hudhali poets generally. ${ }^{37}$ In my study of Hudhali poetry, I have concluded that it was not only Hudhali poets who used hunting scenes in their elegies, but other pre- and early Islamic poets as well. The number of such elegies is, however, fewer than modern research generally supposes. They are listed in my study. ${ }^{38}$ Of interest here are those of the Hudhayl tribe. Seven of them are: Poem 4 by Abu Kabir, who, according to Joseph Hell, lived between 550 and 600 A.D., two generations before Sa'ida and Abu Dhu'ayb; ${ }^{39}$ Poem 4 by Qays b. al-'Ayzara, a contemporary of the pre-Islamic poet Ta'abbata Sharran, who lived between 575 and 625, a generation before Sa ${ }^{c}$ ida and Abu Dhu'ayb; ${ }^{40}$ Poems 1 and 15 by Sakhr al-Ghayy, a mukhadram poet, who lived perhaps a generation before Sa ida and Abu Dhu'ayb, or in their generation; ${ }^{41}$ and finally Poems 1 and 16 by Abu Khirash and Poem 4 by Usama b. al-Harith, both contemporaries of Sa'ida and Abu Dhu'ayb. ${ }^{42}$ Although these poems indicate that use of animal stories in elegies was a familiar tradition among the Hudhali poets, their structure and content show no direct influence on Abu Dhu'ayb's 'ayniyya in the way that the two poems of Sa'ida do. Further examination of this is beyond the scope of this article, meriting a study of its own.

Arabic literature is acquainted with the term mu'arada (a literary imitation or emulation) in which a poem imitates the same rhyme and meter of another, often attempting to surpass the original. ${ }^{43}$ Some of the oldest examples of the mu'arada are the poems of the two pre-Islamic poets Imru' al-Qays and 'Alqama l-Fahl, who compete to most skillfully describe the horse. ${ }^{44}$ Of interest is that muaradas are not common, at least not in pre-Islamic and early Islamic poetry, between poets and their transmitters (rāwis̄), although it seems reasonable that rāwīs and their master poets might compete. In addition to the $m u^{\text {' }} \bar{r} \mathrm{rad} a$, in which the original poem is very clearly mirrored in the later, classical Arabic literature shows other types of poetic influence through a wide net of intertextual relationships between one poem and other contemporary or older works. It is untrue that imitations and influence are particularly

\footnotetext{
${ }^{34}$ Al-Sukkari, Kitab, 1165-71.

${ }^{35}$ Goldziher, "Bemerkungen," 307-39; Pellat, "Marthiya," 602-3; Suzanne Stetkevych, "The Ritha' of Ta’abbata Sharran: A Study of Blood-Vengeance in Early Arabic Poetry," Journal of Semitic Studies 31, no. 1 (1986): 27-45; Ibid., "Ritual and Sacrificial Elements in the Poetry of Blood-Vengeance: Two Poems by Durayd ibn al-Simmah and Muhalhil ibn Rabiah," Journal of Near Eastern Studies, 45, no. 1 (1986): 31-43.

${ }^{36}$ Renate Jacobi, "Bemerkungen zur frühislamischen Trauerpoesie," Wiener Zeitschrift für die Kunde des Morgenlandes 87 (1997): 95-96.

${ }^{37}$ Muhammad Ahmad Bariri, "al-Malaka al-Shi'riyya wa-l-Tafa ul al-Nassi. Dirasa Tatbiqiyya 'ala Shi'r al-Hudhaliyyin," Fusul 8, no. 3-4 (1989): 25-27; Bariri, al-Uslubiyya, 38-96.

${ }^{38}$ See a discussion of these poems in Husayn, al-Shakl wa-l-Madmun, 120-25.

${ }^{39}$ Al-Sukkari, Kitab, 1090-93. Hell, “Der Islam ," 81.

${ }^{40}$ Hell, "Der Islam," 81; al-Sukkari, Kitab, 597-600; Sezgin, Geschichte, 252-53.

${ }^{41}$ Al-Sukkari, Kitab, 245-53, 287-92; Sezgin, Geschichte, 145-46, 262.

${ }^{42}$ Al-Sukkari, Kitab, 1189-95, 1234-36, 1295-1301; Hell, "Der Islam," 82.

${ }^{43}$ A. Schippers, "Mu'arada," The Encyclopaedia of Islam, 7: 261. For other usages of the term mu'arada, see Ali Ahmad Hussein, "Singularity and Innovation in Ancient Arabic Poetry: Ihtidha", Muiarada and Lafz-Ma'na According to the Classical Critics" (Hebrew), in Ben 'Ever la-'Arav: Contacts between Arabic Literature and Jewish Literature in the Middle Ages and Modern Times, ed. Ali Ahmad Hussein and Ayelet Oettinger, A Collection of Studies Dedicated to Prof. Yosef Tobi on the Occasion of His Retirement (Haifa: University of Haifa, 2014), 6: 37-40.

${ }^{44}$ Sumi, Description, 19-60.
} 
common between poets from the same family, or between poets and their rāwīs. ${ }^{45}$ In many instances, despite kinship between poets or the relationship between poet and transmitter, the poets are not influenced by-or at least do not show that influence of-family or master poet, although some Hudhali poets from the same tribe do share some characteristics and content. ${ }^{46}$ The influence on Abu Dhu'ayb's 'ayniyya of Sa ida's two poems is not, as shown above, deniable. ${ }^{47}$ It is, however, still difficult to consider the 'ayniyya as a pure mu'arrada of Sa'ida's poems. They have no common meters or rhyme letters, and Abu Dhu'ayb's poem blurs its relationship with those of Sa'ida. "Concealed mu'arada" may be a useful way of describing this type of literary influence, in which imitation is skillfully hidden.

Abu Dhu'ayb's 'ayniyya grew in fame in the decades following his death, becoming far more influential than either of Sa'ida's two poems. ${ }^{48}$ By the time of 'Abd al-Malik b. Marwan, an Umayyad caliph (r. 685-705), it was one of seven poems that the caliph himself apparently chose to for his son's education, together with four other pre-Islamic poems. These included the long and famous ode known as muiallaqāt composed by 'Amr b. Kulthum, al-Harith b. Hilliza, 'Antara b. Shaddad, and 'Abid b. al-Abras. The same selected anthology contained another famous pre-Islamic poem, composed by a mukhadram poet Suwayd b. Abi Kahil al-Yashkuri. It was a multi-themed poem in which love affairs with more than one partner were narrated, along with the poet-protagonist's lengthy praise of his tribe. ${ }^{49}$ The seventh poem in this collection was an Islamic ode by Aws b. Maghra' al-'Uqayli (d. ca. 695). Suwayd's work was included because of his fame and the poem's gnomic ideas, and that of Aws because of its mention of the Prophet Muhammad and the first three orthodox caliphs, while ignoring the fourth caliph ('Ali b. Abi Talib, r. 632-656), an enemy of the Umayyad dynasty to which 'Abd al-Malik belonged. The 'ayniyya of Abu Dhu'ayb was selected because of its popularity at the time. ${ }^{50}$ The many impressionistic gnomic and philosophical notions of life and death that appeared in its introduction pleased the audience and possibly contributed the 'ayniyya's fame. ${ }^{51}$

When the second Abbasid caliph Abu Jafar al-Mansur (r. 754-775) mourned the death of his son, this poem was the only elegy that came to his mind, as the following narrative illustrates.

When Ja'far b. al-Mansur the Elder died, al-Mansur marched in his funeral procession from Medina to the cemetery of the Quraysh tribe. All the people marched with al-Mansur until he buried the Elder. Then he returned to his palace. He asked al-Rabic [b. Yunus, a courtier and vizier]: "O Rabi', search my family for anyone who can recite 'Why do you grieve at Fate and its mischief?' I need to be consoled of my calamity." Al-Rabic said: "I went out to the Hashim family, all of whom were in attendance, and asked them about the poem. None could remember it. I returned and told al-Mansur. He said: 'I swear that having no one in my family who knows this poem by heart, because of their indifference to literature, is a harder loss than the passing of my son!' Then he said: 'Search among the leaders and the commoners for anyone who knows the poem!

\footnotetext{
${ }^{45}$ Bräunlich, "Betrachtungsweise," 201-69.

${ }^{46}$ See, for example, Bariri, “al-Malaka," 25-27; Bariri, al-Uslubiyya; Husayn, al-Shakl wa-l-Madmun; Maysa' Qatlan, Shic $r$ Sa'ida b. Ju'ayya al-Hudhali. Dirasa wa-Tahqiq (MA thesis, Damascus University, 2003), 67.

${ }^{47}$ The poetry of Saida and Abu Dhu'ayb includes some poems in which the same theme is treated differently; see Sumi, Description, 61-91.

${ }^{48}$ The question of what makes a certain poem famous is interesting and deserves study. This may differ from poem to poem and occasion to occasion. Some poems (such as the mantle ode of Ka’b b. Zuhayr, see Diem, Studien zu Überlieferung) have won renown through the admiration and reward of a famous patron (the Prophet Muhammad, in this instance).

${ }^{49}$ See a discussion of the uniqueness of this poem in Ali Ahmad Hussein, "One Qasida with Several Chaste Love Affairs in Light of al-Mufaddaliyyat and al-Asma'iyyat," Middle Eastern Literatures 14, no. 1 (2011): 10-19.

${ }^{50}$ M. J. Kister, “The Seven Odes: Some Notes on the Compilation of the Múallaqat," Rivista Degli Studi Orientali 44, no. 1 (1969): 30, 35.

${ }^{51}$ Mu'awiya b. Abi Sufyan, who was mentioned previously (footnote 7) as a Syrian governor and later became the first Umayyad caliph (re. 661-680), recited a verse of the poem before his death. For the gnomic verses, highly praised by classical critics, see Abu Mansur al-Tha'alibi, al-I'jaz wa-l-Ijaz (Egypt: al-Matba'a al-'Umumiyya, 1897), 14-17; and Kister, "Seven Odes," 35. See also Safiyy al-Din Abu l-Fath 'Isa b. al-Buhturi al-Halabi, Uns al-Masjun wa-Rahat al-Mahzun, ed. Muhammad Adib al-Jadir (Beirut: Dar Sadir, 1997), 209-10.
} 
I like to hear it recited.' I went out and asked the people, but found no one other than an old teacher who had just finished his class. I asked him: 'Do you remember any poetry by heart?' He answered: 'I surely do! I remember the poetry of Abu Dhu'ayb.' I said: 'Recite it!' He started with the 'ayniyya, and I told him: 'You are the man I am looking for.' I brought him to al-Mansur, who asked him to declaim the poem. When he recited 'For Fate never shows good will to those who sorrow!' al-Mansur said: 'I swear, he is right! Repeat that, one hundred times. I want this hemistich fixed in my mind.' The old man did so, then continued the recitation. When he reached the verse 'Fate-there survives not against its accidents the dark-backed ass with its herd of four plump she-asses,' al-Mansur said: 'With this verse, it appears that Abu Dhu'ayb has consoled himself!' Then he ordered the old man to leave. I followed him and asked him: 'Did the Emir of the Believers reward you?' He showed me a purse which contained a hundred dirhams."

In the anecdote, the fact that the poem was unknown in Medina illustrates the ignorance of its residents, not that Abu Dhu'ayb's 'ayniyya was not famous. For al-Mansur, there was no better elegy than the 'ayniyya to ease the pain of losing his son.

Three important points emerge from this narrative. First, from the late Umayyad into the Abbasid eras, the poem was considered an expression of profound grief for the death of sons, and was chosen to assuage the agony of a bereaved father. Second, its introduction had the greatest emotional impact on its audience. Third, the last three paragraphs of this poem soothed the soul of the poet-protagonist himself.

The belief that Abu Dhu'ayb lost his five sons to the plague after moving to Egypt is the traditional background for his 'ayniyya. This convention comes from Abu Sa'id al-Sukkari, who collected and interpreted the poetry of the Hudhayl, the tribe to which Abu Dhu'ayb belonged, and who died in 888. Al-Sukkari's sources were twofold, [Abu?] 'Umara b. Abi Tarafa and 'Abd Allah b. Ibrahim al-Jumahi. Little is known of either. Ibn Abi Tarafa was a member of the Hudhayl and a contemporary of the celebrated Basrian Arabic philologist al-Asma $i$, who lived in the 8th to 9th centuries (d. 828); Ibrahim al-Jumahi transmitted the poetry of the Hudhayl and lived at the same time as the poet Ibn Harma in the 8th century, dying some four decades before Ibn Abi Tarafa in about $786 .{ }^{53}$ The oldest sources for this narrative therefore date from a century or more after the poet's death. Later sources increase the number of Abu Dhu'ayb's dead sons to seven, and by the time of Ibn Aydamir (d. 1310), the compiler of one of the longest anthologies of Arabic poetry, they number sixty-three, all of whom succumb to the plague in Egypt, as if each of the poem's sixty-three verses represents a stricken son. ${ }^{54}$

The deadly plagues that raged down the centuries in Muslim lands from the time of Prophet Muhammad are detailed by historians and classical Arabic scholars. The plague of 'Amwas, for example (named for the Palestinian town 'Amwas, or Emmaus), which erupted in Syria in the year 638 or 639 and killed many Muslims, is recorded in several texts and has an entry in the third edition of The Encyclopaedia of Islam. ${ }^{55}$ Although several severe plagues are reported in Egypt, none occur during the period when Abu Dhu'ayb is believed to have lived there. There is an account by al-Zubayr b. al-'Awwam, father of the anti-Umayyad caliph 'Abd Allah b. al-Zubayr, who was sent to Egypt in 641 as part of the conquering force. En route, he receives an alarming message from the "Emirs of Egypt" that there is plague in the land. He nevertheless leads his troops into the country. As there is

\footnotetext{
${ }^{52}$ Abu al-Faraj al-Isfahani, Kitab al-Aghani, 3rd ed., ed. Ihsan 'Abbas et al. (Beirut: Dar Sadir, 2008), 6:192-93.

${ }^{53}$ In Yaqut al-Hamawi's Mu'jam al-Buldan, Ibrahim al-Jumahi is identified as "rāwiyat shi' ri Hudhayl" (5: 65), the transmitter of the Hudhli poetry. Al-Sukkari, Kitab, 245-53, 287-92; Sezgin, Geschichte, 145-46, 262. Some narratives describe a conversation between the two. See, for example, Jamal al-Din ibn Manzur, Mukhtasar Tarikh Dimashq li-l-ibn 'Asakir, ed. Rawhiyya al-Nahhas et al. (Damascus: Dar al-Fikr li-l-Tibáa wa-l-Nashr wa-l-Tawzi', 1984), 87.

${ }^{54}$ Muhammad b. Aydamir, al-Durr al-Farid wa-Bayt al-Qasid, ed. Kamil Salman al-Jubburi (Beirut: Dar al-Kutub al-'Ilmiyya, 2015), 255-57.

${ }^{55}$ Justin K. Stearns, “Amwas, Plague of,” The Encyclopaedia of Islam, Three, https://referenceworks.brillonline.com/ browse/encyclopaedia-of-islam-3.
} 
no historical report of their encountering any true plague either during the invasion or after it, it is likely that the emirs were attempting to prevent the Muslim onslaught. ${ }^{56}$

Elegies comprise the majority of poems in Abu Dhu'ayb's diwan. Nushayba, an otherwise unknown member the poet's tribe, was elegized in no fewer than five poems (Poems 5, 7, 11, 13, and 14). Other than elegies, Abu Dhu'ayb's canon commemorated minor events. One example is a poem that accused his cousin of a relationship with a woman whom the poet loved (Poems 14, 27, 28, and 29). Another praised 'Abd Allah b. al-Zubayr, mentioned above, the man with whom the poet was sent from North Africa to the caliph in Medina with news of the Muslim military success (Poem 25). There was, however, no poem or even a single verse other than the cayniyya in which the poet elegized the death of his sons. Nor was there any evidence either for or against their premature death. Mourning the death of a son was infrequent in classical and medieval Arabic poetry, but when it appeared it was normally as a series of poems composed by the same bereaved father. ${ }^{57}$ Writing more than one elegy to express the bereaved poet's profound grief for a single relative was reasonable, indicating the poet was in pain and used his talent to express his agony. ${ }^{58}$

Sa'ida's diwan includes two poems in which he memorialized the death of his son (Poems 8 and 11). There is no easy explanation as to why no poem in Abu Dhu'ayb's diwan other than his 'ayniyya elegized his sons. Two possible hypotheses are raised: first, Abu Dhu'ayb composed other elegies for his sons, all of which, other than the ayniyya, were lost. If this is so, why did elegies for his other relatives survive? Second, as a faithful believer, the bereaved father had to profess acceptance of the death of his children, as Islam instructs. Why, then, did Abu Dhu'ayb highlight throughout the introduction to his 'ayniyya his inability to be patient? It is clear from the poem that he pretended patience only in the presence of envious rivals, because he feared their mockery should they perceive him as weak. That is, it was in no way a matter of faith. ${ }^{59}$

It is difficult to refute that the death of his sons was the true reason Abu Dhu'ayb composed this poem. It is equally difficult to verify that this is a true elegy to a life event, the poet's loss of his sons. It can neither be proved that this literary work was inspired by a historical event experienced by the father-poet, nor that the dead sons were a literary fiction, part of an effort by Abu Dhu'ayb to outdo Sa'ida's two poems by replacing the lament about aging with the anguish of the bereft father and thus make his poem more remarkable than either of those by his teacher. The reasons that Abu Dhu'ayb made this substitution may have been to give greater emotional impact (than Sa'ida's work) to both the introduction and the poem as a whole. Dead sons are, of course, far more emotion-provoking than an aged person, attracting and impassioning larger audiences. Because of Abu Dhu'ayb's substitution, the caliphs Mu'awiya (footnote 51) and Abu Ja'far al-Mansur, in their grief, both recalled Abu Dhu'ayb's poem rather than those of Saida. Replacing aging with the loss of sons in the poem's introduction also is another way of blurring similarity to Sa'ida's poems and signaling that the 'ayniyya is an original work, rather than an imitation (or mu'a $r a d a$ ) of the master. In any case, this replacement made Abu Dhu'ayb's 'ayniyya more memorable than either of his teacher's two poems. Whatever underlay the composition of the famous 'ayniyya, the literary influence of Sa ida's poems, especially Poem 2, on that of Abu Dhu'ayb is undeniable. Generations, however, recall the verses of Abu Dhu'ayb's 'ayniyya, whereas the two poems of Sacida are all but forgotten.

\footnotetext{
${ }^{56}$ See, for example, Ibn Hajar al-'Asqalani, Fath al-Bari. Sharh Sahih al-Bukhari (Beirut: Dar al-Márifa, 1959), 187. Some sources say that al-Zubayr "feared the plague," with no mention of the emirs of Egypt. See Abu Bakr b. Abi Shayba, al-Kitab al-Musannaf fi al-Ahadith wa-l-Athar, ed. Kamal Yusuf al-Hut (Riyad: Maktabat al-Rushd, 1988), 116.

${ }^{57}$ Thomas Bauer, "Communication and Emotion: The Case of Ibn Nubatah's Kindertotenlieder," Mamluk Studies Review 7 (2003): 49-52.

${ }^{58}$ Pellat, "Marthiya," 603.

${ }^{59}$ M. M. Badawi, "From Primary to Secondary Qasidas: Thoughts on the Development of Classical Arabic Poetry," Journal of Arabic Literature 11 (1980): 4; Arazi, “Thrène," 77-78.
} 


\section{APPENDIX}

POEM 2, BY SA'IDA B. JU'AYYA

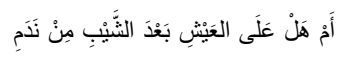$$
1
$$

Oh, if I knew! Is there any security from old age? Is there any recompense for life when hair turns gray?

$$
2
$$

Grayness of hair is a fatal disease. There is no cure for it, even for a man who was once healthy and knew how to face danger.

$$
3
$$

He became drowsy, but did not sleep enough. Had his tribe not been moving on today, he would not have risen.

$$
\text { وَفِي مَفَامِلِهِ غَمْزٌ مِنَ العَسَمِ }
$$

$$
4
$$

He suffers pain in his shoulders and back. His stiff joints make him limp.

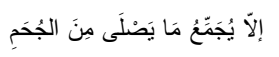$$
5
$$

If you visit him in summer, you will find him collecting burning coals.

$$
6
$$

Until it is said, while he lies to one side behind the tent: "The tribe has already started to move.

Stand up and prepare yourself!"

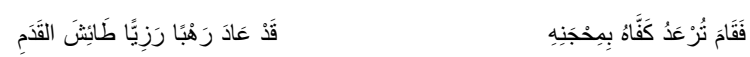

He stood. His hands trembled, grasping his crooked stick. He was thin, fatigued, and he marched unsteadily.

$$
8
$$

By God, none can guard his life against Time, not even a mountain goat, with knotted horns that twist behind its ears, and white shanks!

$$
9
$$

Which shelters in lofty mountains; on high peaks where the white birch and mountain elm grow.

$$
10
$$

Above are the frigid mountain crests. Below, the foothills, draped in clematis and jasmine.

$$
11
$$

It gazes constantly at the șawm trees and the hiding places they conceal. It is lean in belly, afraid to stop long enough for its urine to flow.

$$
12
$$

Until Fate brings an archer. He has a light bow and white arrows, their sides resembling the saham tree.

$$
13
$$

The mountain goat maintained its watch on that place until evening gave way to full dark. 


$$
14
$$

As night fell, after its constant alertness, the mountain goat relaxed and nibbled on the nim and the katam trees.

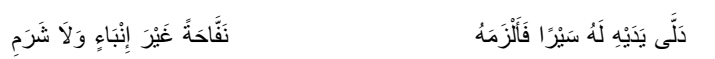

The archer took aim as he approached the beast, and sent his arrow deep inside it. He did not miss nor deliver a wound that merely glanced.

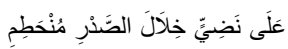

$$
16
$$

The mountain goat turned near the mountain ridge to flee [the hunter/arrow], but fell, the arrow deep inside its chest.

$$
17
$$

There was a herd of antelope, their withers were combed. They stood like pearls fallen from a necklace.

$$
18
$$

They remained upright, placing their feet evenly side by side, upon the stony ground, dehydrated on a burning summer day.

$$
19
$$

Their water was gone. They grew lean. They were ready to go anywhere that they saw lightning flash.

$$
20
$$

Until, after a while, a dim continuous lightning attracted them. They passed the remainder of the night in great excitement, the lightning not ceasing.

$$
21
$$

As if what alights its summits after calmness was like fire marching through wood.

$$
222
$$

It moved back and forth. From the clouds, it flashed above the earth, revealing a surface which flowed with abundant water.

$$
23
$$

The antelope hastened through the night toward that place, not slowed by either the soft ground or the darkness.

$$
24
$$

When night dispelled, the antelope saw, to their alarm, a horseman with a sharp and deadly lance.

$$
25
$$

He drove them toward open ground, and pursued them. They fled from shelter into the open.

$$
26
$$

He turned on them with a long spear. Covered in blood, they fell to the ground.

$$
27
$$

It was an inevitable death given the long days and endless nights. 


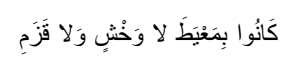

$$
28
$$

Do the accidents of Time spare those in the region of Mayat? They were not inferior people nor ignoble.

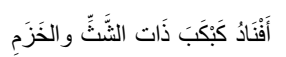

$$
29
$$

It betrayed an entire people, who were like the slopes of Mount Kabkab where hop bushes and dragon trees grow.

$$
\text { لا مُنْتَأَى عَنْ جِياضِ المَوْتِ والَحِمَِ }
$$

$$
30
$$

Ibn Ju'shum brings them the news. None can escape the depths of Death and Fate.

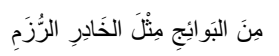$$
31
$$

He feared for them, for the disasters that may come-like a lion lurking, leaping upon its prey.

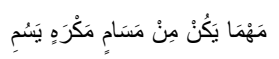

32

A courageous man. Pregnant women miscarry their babies because they dread him. Where there is a dangerous pasture, he goes forward.

$$
33
$$

They were part of the noble hums tribes. They had never known fear until they saw their enemies plundering their women and livestock.

$$
34
$$

They set upon them from hollow-eyed horses, the reins grasped in their hands. The beasts were always kept close to the tents. In their fear, their riders hurriedly harnessed them.

$$
35
$$

Whenever they are fearful, they go armored, urging their horses to move as quickly as they can, spurring them with their legs and whips.

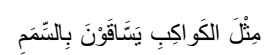

$$
36
$$

Each side drew razor-sharp Yazanite spears, shining like stars; threatening one another as if with poison.

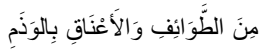

$$
\begin{aligned}
& 37
\end{aligned}
$$

Made in Bosra, the swords fell on their sides and necks, cutting them as easily as if they were leather strips holding a bucket.

$$
38
$$

They dispatched kings to the ground, hither and yon, slicing them as if cutting through soft leather.

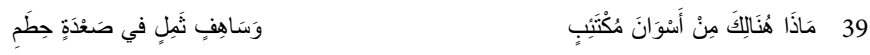

What is left? One who mourns and sorrows, one who flounders, pierced by a broken lance, as if intoxicated.

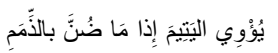

$$
\begin{aligned}
& 40
\end{aligned}
$$

A clement and generous noble was among those who perished, a man who gave shelter to orphans when none other would.

$$
41
$$


He was a tall man, his neck and face streamed blood, and his loud screams were like those of a vulture.

$$
\text { كَالفَفْلِ قَرْقَرَ وَسْطَ الهَجْمَةِ القَطِِِ }
$$$$
42
$$

He had ridden into the heart of the battlefield, with the first wave of horses. He was like a lustful camel-a male shouting out among a large herd of female camels.

$$
43
$$

A freeborn woman was put behind the camel's saddle, forced either to ride or walk.

$$
\text { بَرْفُلْنَ بَعْدَ ثِيَابِ الخَالِ فِي الرَّدُمْ }
$$$$
44
$$

Tears flowed from behind her eyelids; she was clothed in old, patched garments, not the soft Yemenite clothing she once wore.

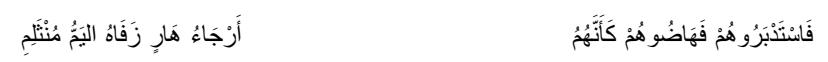

They were ambushed from behind and wiped out, as the sides of a valley are washed away by a torrent.

$$
46 \text { فَجَلَّزُوا بِأُسَارَى فِي زِمَامِهِهُ }
$$

They left quickly, with their captives bound by ropes; the camel herd, as great as the middle of a mountain, was distributed among them.

POEM 4, BY SA'IDA B. JU'AYYA

$$
1
$$

When she saw me, Umama said: "To your enemies, this humility and weariness!"

$$
2
$$

She cried out in pain, because she expected that what had befallen me would make me a heavy burden.

$$
3
$$

Keep your patience! The scant life that remains in me may yet help you!

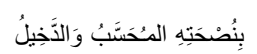$$
4
$$

O Umayma! They still come to me for guidance-the nobles and even the outsiders.

$$
\text { أُخَالِطُهُ أَمَنْمَ وَلَا خَلِيلُ }
$$

$$
5
$$

O Umayma! I have never had family or friend, who hated me!

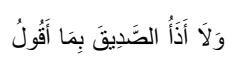$$
6
$$

I flee hatred, and I guard my honor; I never wound a friend with my words.

$$
\text { زَوَاخِرُ وَالغُصُونُ لَهَا أُصُونُ }
$$$$
7
$$

I am descended from noble origin. My firing sticks produce much fire [I am generous]; my branches have roots.

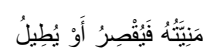


None can protect himself when Death comes for him, whether his life is long or short.

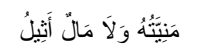$$
9
$$

Neither a child nor great wealth can protect a man whose time of death has been determined.

$$
10
$$

Even if he owns noble white she-camels with stallions that bellow in their midst.

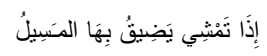$$
11
$$

Their withers are high. The wadi narrows when they walk through it.

$$
\text { نِقَالُ الصَخْرِ وَالخَشَبُ القَطِيلُ }
$$

When he visits the grave, covered by heavy stones and timber,

$$
\text { مُذَرَعَةُة أُمَتْمَ لَهَا فَلِيلُ }
$$$$
13
$$

When he is left buried there, and visited-O Umayma!-at night by a shaggy hyena with striped legs,

$$
\text { كَرَأَسِ العَوْدِ شَهْبَرَةُ نَوُونُ }
$$

With two cracked hooves, with a head like that of an old camel. It is an aged hyena, walking heavily.

$$
\text { حِمَارٌ حَيْثُ جُرَّ وَلََ فَتَنِل }
$$

She spends the night searching for a donkey that was dragged away or a person who was killed.

$$
\text { عِفَاءُ كَالعَبَاءَةٍ عَفْتَلِلِلُ }
$$$$
16
$$

Approaching like a cross-eyed man, who walks at night, she is covered with a layer of hair, so thick it looks like a cloak.

$$
\text { يََيْهَا عِنْدَ جَانِبِهِ نَهِيلُ }
$$$$
\text { فَذَاحَتْ بِالْوَنَائرِ تُمََّ بَدَتْ }
$$

She moved quickly between the graves; then squatted near his, and unearthed it.

$$
\text { سَلِيبًا لَبَسَ فِي يَدِهِ فَتِيلْ }
$$

There he is separated from his livestock, plundered, with nothing with which to defend himself.

$$
19
$$

Even if he seeks a shelter on top of a tall mountain, where only mountain goats live,

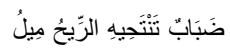$$
20
$$

A distant mountain, its ridge elevated, covered with shrouds of fog driven by the wind,

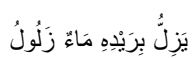

When rain falls from the clouds above it, the water slips along its ridge.

$$
\text { خِلَافَ الوَبْلِ أَوْ سُبَدُ غَبِيلُ }
$$


After the rain, the mountain clefts resemble the sacrificed camels or slippery nightjars.

$$
\text { بِهِ فَتْقُ رَوَادِفُهُ تَزُونُ }
$$

Calamity will surely claim him; or disease will waste away his body. ${ }^{60}$

\footnotetext{
${ }^{60}$ One of the meanings of rawādif, pl. rādifa, is "strike of fate"; see Murtada al-Zabidi, Taj al-'Arus min Jawahir al-Qamus (Dar al-Hidaya, n.d.), 23:331.

Cite this article: Hussein AA (2021). Two Sources for Abu Dhu'ayb al-Hudhali's Famous Elegy. International Journal of Middle East Studies 53, 213-233. https://doi.org/10.1017/S0020743821000027
} 